\title{
Appetite-Regulating Hormone
}

National Cancer Institute

\section{Source}

National Cancer Institute. Appetite-Regulating Hormone. NCI Thesaurus. Code C104429.

Appetite-regulating hormone (117 aa, $\sim 13 \mathrm{kDa}$ ) is encoded by the human GHRL gene.

This protein is involved in satiety, thirst and anxiety and regulating growth hormone release. 